\title{
Pengelolaan Konten Media Sosial Korporat Pada Instagram Sebuah Pusat Perbelanjaan
}

\author{
Siti Muslichatul Mahmudah ${ }^{\mathbf{1}}$, Muthia Rahayu ${ }^{2}$ \\ ${ }^{1,2}$ Program Studi Ilmu Komunikasi, Universitas Mercu Buana \\ Email: sitimuslichatul.office@gmail.com
}

\begin{abstract}
The use of social media Instagram has increased to the corporate level, such as shopping centers which have visitors to finding out all mall information via Instagram. Therefore we need the management of social media content to be a means of communication between the company and its audience. This research uses constructivist paradigm. The theory used is The Circular Model of Some by Regina Luttrell in his book Social Media How to Engage, Share, and Connect. This research method is descriptive with a qualitative approach. Data collection techniques used interviews with key informants in this research were the management team of a social media shopping centers and the informants are visitors who are also followers of the mall's Instagram. This research uses source triangulation for data validity techniques. From the results that content management on instagram, the aspect of sharing begins with the purpose of using social media for corporates. Optimize aspects make a schedule and utilizing the features available on Instagram. The manage aspect is make media monitoring reports as an evaluation and accountability. In the aspect of engaging, establishing good relations with the online community to get instagram exposure on the content produced.
\end{abstract}

Keywords: Social Media Management, Content, Instagram.

\begin{abstract}
Abstrak: Penggunaan media sosial Instagram mengalami pengingkatan hingga pada level korporat, seperti pusat perbelanjaan (Mall) yang memiliki pegunjung dengan karakteristik mencari tahu segala informasi mal melalui instagram. Oleh karena itu dibutuhkan pengelolaan konten media sosial untuk menjadi sarana komunikasi antara perusahan dengan khalayaknya. Penelitian ini menggunakan paradgima konstruktivis. Teori yang digunakan yaitu The Circular Model of Some oleh Regina Luttrell dalam bukunya Media Sosial How to Engage, Share, and Connect. Metode penelitian ini ialah deskriptif dengan pendekatan kualitatif. Teknik pengambilan data ialah wawancara kepada key informan yaitu tim pengelola dari social media perusahaan khususnya pusat perbelanjaan (Mall) dan informannya ialah pengunjung pusat perbelanjaan (Mall) yang juga follower dari akun instagram Mal tersebut. Penelitian ini menggunakan triangulasi sumber untuk teknik keabsahan data. Dari hasil penelitian diketahui bahwa pengelolaan konten pada media sosial instagram, aspek share dimulai dengan memahami tujuan penggunaan media sosial bagi korporat. Aspek optimize, yaitu membuat jadwal posting serta pemanfaatan fitur yang tersedia pada instagram. Aspek manage dilakukan dengan membuat report media monitoring sebagai evaluasi serta pertanggung jawaban kepada manajemen perusahaan. Pada aspek engage, menjalin hubungan baik dengan komunitas online untuk mendapatkan instagram exposure pada konten yang dihasilkan.
\end{abstract}

Kata Kunci: Pengelolaan Media Sosial, Konten, Instagram.

\section{Pendahuluan}

Pada era digital saat ini, kita tengah dihadapi dengan segala perkembangan trend serta update yang terjadi di dunia digital. Hal ini sangat berhubungan dengan kebutuhan manusia akan informasi dan teknologi. Guna melengkapi kebutuhannya, manusia menggunakan berbagai cara dan media. Tak terlepas juga dengan perkembangan media komunikasi yang semakin signifikan dengan kecanggihan teknologi di 


\section{Jurnal Komunikasi Nusantara}

\section{E-ISSN. 2685-7650}

Vol. 2 No. 1 (2020), pp 1-9

DOI: https://doi.org/10.33366/jkn.v2i1.39

seluruh dunia. Media digital memiliki keunggulan dalam peyampaian pesan yang dapat dikirim dengan kapasitas data yang cukup besar dan media penyimpanannya yang tidak terbatas karena menggunakan jaringan internet. Perkembangan teknologi dan internet yang sangat pesat ini yang telah membantu masyarakat dalam mendapatkan dan menyampaikan informasi. Jangkauan dari media komunikasi digital ini memang bisa secara luas menjangkau khalayaknya.

Sebanyak 64,8 \% dari total populasi penduduk Indonesia ialah pengguna internet aktif dan hal ini mengalami peningkatan jumlah dari tahun sebelumnya yaitu diangka 54,68\%. Begitu juga dengan penggunaan dan perkembangan media sosial terus berkembang hingga saat ini. Sejalan dengan mudahnya akses internet bagi banyak orang, internet of things, dan faktor-faktor lainnya. Media sosial saat ini telah menjadi bagian dari gaya hidup. Masyarakat memanfaatkan media sosial sebagai sarana untuk berbagi tentang segala hal mengenai keseharian mereka, ataupun momen-momen penting dalam hidup mereka agar dapat berbagi dengan khalayak ramai. Tidak hanya itu, media sosial juga dapat berfungsi sebagai media untuk berbagi berita dan pengetahuan sehingga dapat menambah informasi bagi para penggunanya. Total pengguna mencapai 150 juta pengguna, ini berarti mayoritas penggunaan internet untuk bersosialisasi melalui media sosial. Jumlah pengguna media sosial ini mencapai $56 \%$ dari jumlah total penduduk Indonesia, dengan pengguna berbasis mobilenya mencapai 130 juta.

Tingginya penggunaan media sosial di Indonesia juga menciptakan peluang dalam hal strategi perusahaan. Jika sebelumnya, iklan di media massa menjadi media yang paling digemari untuk alat promosi perusahaan. Belakangan ini, sudah banyak juga perusahaan yang memanfaatkan media sosial sebagai cara mereka menjalin komunikasi dengan para khalayaknya. Media sosial bisa menjadi sarana untuk memudahkan interaksi dengan kemudahan seperti penyebaran informasi dari satu individu ke individu lain menjadi sangat mudah. Media sosial merupakan perkembangan teknologi berbasis internet yang memungkinkan penggunanya berinteraksi secara langsung dalam beberapa bentuk (Zarella, 2010).

Media sosial menurut Philip Kotler dan Kevin Keller (Kotler, 2012), merupakan sarana bagi konsumen untuk berbagi informasi teks, gambar, audio, dan video dengan satu sama lain dan dengan perusahaan dan sebaliknya. Peran media sosial semakin diakui dalam mendongkrak kinerja bisnis. Media sosial memungkinkan bisnis dapat mengubah cara berkomunikasi dengan pelanggan, memasarkan produk dan jasa serta saling berinteraksi dengan pelanggan yang bertujuan untuk membangun hubungan yang baik (Kotler, 2010).

Menambahkan penjelasan diatas, media sosial juga merupakan sarana yang sangat tepat untuk pemasaran. Segala kemudahan mengakses ke berbagai penjuru tempat hanya dengan melalui berbagai jenis gadget memudahkan pemasar untuk berkomunikasi dan lebih dekat dengan kosumen. Segala kenyamanan yang bisa didapatkan melalui media sosial inilah yang memicu perkembangan pesat pemakaiannya (Danis, 2011).

Salah satu jenis media sosial popular yang mendukung dalam mengunggah dan berbagi gambar adalah instagram. Sebagai media sosial dengan bentuk jejaring sosial berbagi foto/video, instagram juga digunakan oleh perusahaan sebagai media informasi untuk memenuhi kebutuhan khalayaknya. Terlebih bagi perusahaan yang memiliki customer sebagai pengguna aktif instagram yang selalu mengikuti update dari postingan instagram perusahaan. Seperti pada jenis perusahaan pusat perbelanjaan atau lebih sering dikenal dengan sebutan mall. Di mana customer sebuah mal biasanya memiliki karakteristik untuk mencari tahu segala informasi terkait dengan mall yang ia ingin kunjungi melalui media sosial milik mal tersebut, yaitu instagram karena dinilai lebih sering update informasi baik berupa informasi kegiatan/acara yang akan 


\section{Jurnal Komunikasi Nusantara}

\section{E-ISSN. 2685-7650}

Vol. 2 No. 1 (2020), pp 1-9

DOI: https://doi.org/10.33366/jkn.v2i1.39

berlangsung, promo belanja, fasilitas, dan lain sebagainya. Pengunjung mal yang tersebar di beberapa titik baik itu di wilayah lokasi tempat mal tersebut maupun wilayah terdekat sekitarnya memerlukan informasiinformasi yang tentunya berkualitas agar dapat menjawab kebutuhannya sehingga ia menjadi tahu akan hal yang ia ingin cari ataupun ketahui sebelumnya.

Semakin meningkatnya pengguna instagram terlebih media sosial ini dapat digunakan secara mobile di perangkat bergerak seperti telepon genggam atau komputer tablet dan juga banyak fitur-fitur dalam instagram yang menarik minat para penggunanya untuk lebih eksplor platform media sosial Instagram maka kelebihan - kelebihan ini yang menjadikan siapapun akan senang dan mudah mengakses Instagram dimanapun dan kapanpun. Pada sisi semakin pesatnya pengguna instagram ini juga yang ditangkap sebagai peluang perusahaan menjadikan Instagram sebagai salah satu media informasi untuk menjangkau khalayaknya.

Keunggulan lainnya media sosial Instagram sebagai media informasi yang dapat digunakan oleh perusahaan ialah pada instagram juga bisa dihubungkan dengan akun media sosial lainnya sehingga dengan satu kali post di instagram, foto tersebut bisa kita share juga ke akun media sosial lain seperti twitter dan juga facebook. Ditunjang juga dengan penggunaan hastag pada setiap postingan di instagram, layaknya sebuah keyword pada search engine, fungsi dari hashtag pada instagram tidak jauh berbeda dari media sosial twitter, dengan menggunakan hastag pengguna dapat langsung masuk ke topik yang ingin dilihat atau dicari. Hashtag ini tentu akan sangat membantu dalam penyebaran informasi melalui konten yang diposting pada instagram. Dengan mencantumkan hashtag terpopuler pada caption konten yang di upload atau membuat hashtag unik yang hanya dimiliki sebuah konten tertentu. Tepat mecantumkan hashtag akan mempercepat proses penyebaran informasi.

Sehubungan dengan kondisi saat ini, maka informasi datang dengan sangat cepat melalui media sosial. Untuk itu masyarakat perlu selektif dalam menerima informasi. Hal tersebut bertujuan agar penerima informasi tidak mudah terpengaruh oleh banyaknya informasi yang datang. Seseorang dapat mencarinya secara online dimana terdapat ribuan informasi. Oleh karena itu dibutuhkan pengelolaan konten media sosial yang dalam hal ini ialah media sosial milik korporat salah satu nya ialah instagram untuk membantu khalayak perusahaan dalam mendapatkan informasi yang dibutuhkannya dan menjadi media komunikasi antara perusahan dengan khalayaknya. Dengan banyaknya pengunjung mal yang termasuk kedalam masyarakat Indonesia yang mayoritas sebagai pengguna aktif media sosial Instagram, maka memberikan informasi melalui sebuah konten di instagram, bisa menjadi salah satu cara untuk menarik perhatian customer atau followers agar informasi tersampaikan ke pengunjung dengan baik.

Berdasarkan latar belakang yang dijabarkan di atas, maka fokus penelitian ini adalah pengelolaan konten media sosial milik korporat. Dimana di fokuskan kepada konten pada akun Instagram sebuah Pusat Perbelanjaan (Mall). Peneliti ingin menjabarkan maksud dan tujuan yang ingin dicapai dalam penyusunan penelitian ini yaitu untuk mengetahui bagaimana pengelolaan konten media sosial korporat pada instagram sebuah Pusat Perbelanjaan (Mall).

Menurut Atmoko instagram adalah layanan jejaring sosial berbasis fotografi. Instagram juga merupakan suatu aplikasi jejaring sosial yang menggunakan foto sebagai sarana berkomunikasi. Aplikasi jejaring sosial ini akan lebih memudahkan pengguna penyuka fotografi untuk berbagi hasil karya mereka melalui social media. Instagram disukai karena kemudahan dan kecepatannya dalam berbagi foto ditambah beberapa filter bergaya retro yang menarik. Jejaring sosial ini diresmikan pada tanggal 6 Oktober 2010 oleh Kevin Systrom dan Mike Krieger yang mampu menjaring 25 ribu pengguna di hari pertama. Instagram 


\section{Jurnal Komunikasi Nusantara}

\section{E-ISSN. 2685-7650}

Vol. 2 No. 1 (2020), pp 1-9

DOI: https://doi.org/10.33366/jkn.v2i1.39

merupakan kependekan dari kata "instan-telegram". Jadi bila dilihat dari perpaduan dua kata "insta" dan "gram", instagram berarti kemudahan dalam mengambil serta melihat foto yang kemudian dapat dikirimkan atau dibagikan kepada orang lain (Atmoko, 2012).

Konten adalah pokok, tipe, atau unit dari informasi digital. Konten dapat berupa teks, citra, grafis, video, suara, dokumen, laporan-laporan, dan lain-lain. Dengan kata lain, konten adalah semua hal yang dapat dikelola dalam format elektronik (Simarmata, 2011). Menurut Cambridge Dictionary, salah satu pengertian konten adalah "artikel atau bagian yang terdapat dalam majalah atau buku" (the articles or parts contained in a magazine or book). Dalam Business Dictionary, konten memiliki arti:

1. Teks dari dokumen atau publikasi dalam bentuk apa pun. Konten adalah informasi dan komunikasi: jumlah total dari kesegaran, keterbacaan, relevansi, dan kegunaan informasi yang disajikan, dan cara penyajiannya.

2. Esensi dari pesan atau wacana yang dikomunikasikan, sebagaimana dipahami atau diterima oleh audiens yang dituju.

3. Lem 'yang membuat situs web' lengket 'membuat pengunjung kembali, dan membuat mereka tidak pergi.

Dari pengertian di atas, dapat disimpulkan, konten adalah berbagai macam format dan informasi yang tersaji melalui media, khususnya media baru, berupa tulisan, gambar, suara (audio), atau video .

Penelitian ini menggunakan Teori dari Regina Luttrell dalam buku Media Sosial How to Engage, Share, and Connect tahun 2015 menyebutkan The Circular Model of Some bahwa terdapat beberapa tahap yang perlu diperhatikan dalam mengelola media sosial. Terdapat empat aspek dalam model ini, keempat aspek tersebut memiliki kekuatan dalam bagiannya masing-masing, tetapi bersama-sama aspek ini memungkinkan strategi yang solid. Ketika sebuah perusahaan/instansi berbagi (sharing) sesuatu mereka juga dapat mengelola (manage) atau terlibat (engage) dan bahkan mengoptimalkan (optimize) pesan mereka secara bersamaan.

Berikut adalah penjelasan mengenai the Circular model of Some menurut Regina Luttrell dalam bukunya Social Media (Regina, 2015):

1. Share (Menyebarkan): di mana pemirsa saya? Jenis jaringan apa yang mereka gunakan? Di mana kita harus berbagi konten? Sangat penting bagi praktisi media sosial untuk memahami bagaimana dan di mana konsumen mereka berinteraksi. Ini adalah kesempatan perusahaan untuk menghubungkan, membangun kepercayaan, dan mengidentifikasi saluran yang memungkinkan interaksi yang tepat. Dalam hal ini komunikator harus mempunyai strategi dalam menggunakan media sosial serta media sosial apa saja yang digunakan agar komunikasi dapat berjalan efektif dan efisien;

2. Optimize (Optimisasi), apakah ada masalah yang perlu ditangani? Jenis konten apa yang harus dibagikan? Apakah kita memiliki orang yang berpengaruh terhadap perusahaan dan pendukung? Di mana kita sedang diperbincangkan dan bagaimana? Mengoptimalkan setiap rekaman percakapan adalah hal yang terpenting. Sebuah plan komunikasi yang kuat yang dioptimalkan dengan baik menghasilkan dampak maksimum pada pesan, brand, dan juga nilai. Pada bagian ini yakni mengoptimalkan pesan yang ingin disampaikan melalui media sosial. Hal ini dikarenakan setiap media sosial memiliki karakteristik yang berbeda-beda;

3. Manage (Mengatur), apa pesan yang relevan yang harus kita kelola, pantau, dan ukur? Dengan mengatur sistem manajemen media seperti dengan perusahaan Hootsuite dimana dapat terus 


\section{Jurnal Komunikasi Nusantara}

\section{E-ISSN. 2685-7650}

Vol. 2 No. 1 (2020), pp 1-9

DOI: https://doi.org/10.33366/jkn.v2i1.39

mengikuti percakapan yang terjadi di real-time, menanggapi konsumen langsung, mengirim pesan pribadi, berbagi link, memantau percakapan dan mengukur keberhasilan atau kegagalan. Mantriks merupakan bagian integral dalm mengelola strategi sosial. Sebagai praktisi kita harus menggambarkan nilai upaya dan melaporkan kembali ke tingkat eksekutif. Pada tahap ini yakni bagaimana komunikator mengatur media sosial dengan baik. Hal ini dikarenakan seringkali perbincangan terjadi di media sosial secara cepat.

4. Engage (Melibatkan), siapa yang kita libatkan dan bagaimana? Apakah kita ingin konsumen untuk mengambil tindakan pada apa yang telah kita bagikan? Jika demikian, apa yang kita ingin mereka lakukan? Mengelola strategi engagement merupakan hal yang sulit, tetapi ketika perusahaan menyadari manfaat dari keterlibatan otentik hubungan yang tepat dapan dibangun. Dalam pengelolaan media sosial, melibatkan audience dan influencers merupakan komponen yang sangat penting dalam strategi media sosial.

\section{Metode Penelitian}

Metode penelitian yang digunakan adalah jenis metode penelitian deskriptif - kualitatif, bertujuan untuk mendapatkan gambaran yang seutuhnya (mendalam dan kontekstual) mengenai pengelolaan konten media sosial korporat pada instagram sebuah Pusat Perbelanjaan (Mall) dalam memenuhi kebutuhan informasi pengunjung.

Menurut Sukmadinata, penelitian deskriptif kualitatif ditujukan untuk mendeskripsikan dan menggambarkan fenomena-fenomena yang ada, baik bersifat alamiah maupun rekayasa manusia, yang lebih memperhatikan mengenai karakteristik, kualitas, keterkaitan antar kegiatan. Selain itu, penelitian deskriptif tidak memberikan perlakuan, manipulasi atau pengubahan pada variabel-variabel yang diteliti melainkan menggambarkan suatu kondisi yang apa adanya. Satu-satunya perlakuan yang diberikan hanyalah penelitian itu sendiri, yang dilakukan melalui observasi, wawancara, dan dokumentasi (Sukmadinata, 2011).

Berdasarkan keterangan dari beberapa ahli di atas, dapat ditarik kesimpulan bahwa penelitian deskriptif kualitatif yaitu rangkaian kegiatan untuk memperoleh data yang bersifat apa adanya tanpa ada dalam kondisi tertentu yang hasilnya lebih menekankan makna. Di sini, peneliti menggunakan metode penelitian deskriptif kualitatif karena penelitian ini mengeksplor pengelolaan konten media sosial korporat dengan mendeskripsikan pada hasil konten-konten yang telah dipublikasi melalu media sosial Instagram milik Pusat Perbelanjaan (Mall).

Satori mengungkapkan bahwa penelitian kualitatif dilakukan karena peneliti ingin mengeksplor fenomena-fenomena yang tidak dapat dikuantifikasikan yang bersifat deskriptif seperti proses suatu langkah kerja, formula suatu resep, pengertian-pengertian tentang suatu konsep yang beragam, karakteristik suatu barang dan jasa, gambar-gambar, gaya-gaya, tata cara suatu budaya, model fisik suatu artifak dan lain sebagainya (Satori, 2011).

Sedangkan penelitian secara online berbeda dengan penelitian manual hal ini terlihat jelas dari segi kontennya yang bersifat virtual serta kestabilan dari isi konten yang disediakan. Dapat disimpulkan bahwa penelitian kualitatif merupakan metode penelitian yang bermaksud memahami fenomena tentang apa yang dialami subjek penelitian misalnya perilaku, persepsi, motivasi, tindakan dan lain-lain dengan menerapkan strategi verifikasi selama melakukan penelitian. Berdasarkan jenis penelitian, penelitian ini merupakan 


\section{Jurnal Komunikasi Nusantara}

\section{E-ISSN. 2685-7650}

Vol. 2 No. 1 (2020), pp 1-9

DOI: https://doi.org/10.33366/jkn.v2i1.39

penelitian deskriptif. Penelitian deskriptif adalah penelitian yang menjelaskan hasil dari penyelesaian masalah berdasarkan penyajian data, analisis dan interpretasi (Cholid, 2002).

Subjek dalam penelitian ialah sumber yang berkompeten untuk dimintai informasi sehubungan dengan penelitian ini. Hal tersebut dikarenakan subyek penelitian atau yang biasa disebut dengan narasumber merupakan seseorang atau beberapa orang yang berperan sebagai sumber data. Pemilihan informan tentunya harus memenuhi karakteristik yang telah ditetapkan demi diperolehnya data akurat dari sumber-sumber yang memiliki kredibilitas tinggi. Key informan dalam penelitian ini ialah tim pengelola social media perusahaan dan untuk informannnya yaitu pengunjung Pusat Perbelanjaan (Mall) yang sekaligus juga menjadi follower dari akun instagram mal tersebut. Peneliti melakukan wawancara tidak berstruktur (unstructured interview) secara langsung dengan key informan dan informan pada perusahaan yang menjadi objek penelitian.

Teknik analisis data yang dilakukan berdasarkan Flow Analysis Models menurut Miles dan Huberman (Elvinaro, 2011) yakni melalui tiga jenis kegiatan, yaitu reduksi, model Data (Data Display) dan penarikan kesimpulan/verifikasi. Dalam penelitian ini menggunakan triangulasi sumber, dimana peneliti melakukan pengecekan data penelitian yang diperoleh dari sumber wawancara. Triangulasi dengan sumber berarti membandingkan dan mengecek balik derajat kepercayaan suatu informasi yang diperoleh melalui waktu dan alat yang berbeda dalam metode kualitatif (Moleong, 2004).

\section{Hasil dan Pembahasan}

Dari hasil wawancara oleh para narasumber, terdapat beberapa pembahasan serta analisis terkait pengelolaan konten media sosial korporat pada akun instagram sebuah pusat perbelanjaan (Mall). Regina Luttrell dalam buku Media Sosial How to Engage, Share, and Connect tahun 2015 menyebutkan The Circular Model of Some bahwa terdapat beberapa tahap yang perlu diperhatikan dalam mengelola media sosial. Terdapat empat aspek dalam model ini, keempat aspek tersebut memiliki kekuatan dalam bagiannya masing-masing, tetapi bersama-sama aspek ini memungkinkan strategi yang solid. Ketika sebuah perusahaan/instansi berbagi (sharing) sesuatu mereka juga dapat mengelola (manage) atau terlibat (engage) dan bahkan mengoptimalkan (optimize) pesan mereka secara bersamaan.

\section{Share}

Dalam pengelolaan konten pada media sosial instagram, aspek share atau posting menjadi pembahasan yang penting dimulai dari memahami tujuan dari penggunaan platfrom media sosial bagi korporat. Hasil penelitian juga menyatakan bahwa sebuah pusat perbelanjaan (Mall) memiliki target khalayak yang begitu variatif sebagai pengunjung mal tersebut dan alasan peggunaan media sosial yang dimiliki ini juga mengikuti perkembangan trend platform media sosial yang tengah ramai digunakan oleh target khalayaknnya, termasuk kepada pembuatan akun media sosial instagram untuk menjangkau para khalayaknya di media online dengan harapan bisa mendatangkannya menjadi traffic pengunjung mal tersebut. Selain itu juga, konten yang di-share pada akun media sosial korporat yang dalam hal ini ialah pusat perbelanjaan (Mall) menyesuaikan dengan karaktersitik dari masing-masing khalayak pengguna media sosial tersebut, seperti pengguna instargram yang mayoritas berfokus kepada estetika tampilan serta jenis konten story telling yang dapat menarik perhatian agar melihat dan membaca pesan yang disampaikan melalui konten yang di-share. Terlebih lagi dengan jenis konten yang di-share ialah bukan hanya milik internal aktivitas atau acara dari pusat perbelanjaan (Mall) itu saja, namun juga konten promo dari para tenant (brand) yang ada di 


\section{Jurnal Komunikasi Nusantara}

\section{E-ISSN. 2685-7650}

Vol. 2 No. 1 (2020), pp 1-9

DOI: https://doi.org/10.33366/jkn.v2i1.39

dalam mal tersebut sehingga begitu beragam bentuk konten yang dipublikasikan atau di-share pada akun instagram milik sebuah pusat perbelanjaan (Mall).

\section{Optimize}

Dari hasil penelitian menyatakan bahwa pada aspek optimize ini, pengelolaan konten yang dilakukan pada media sosial pusat perbelanjaan (Mall) dengan cara membuat jadwal postingan (scheduling). Hal ini dilakukan dengan bantuan aplikasi sistem penjadwalan otomatis ataupun secara manual untuk case tertentu. Seperti yang disebutkan pada pembahasan sebelumnya karena bentuk dan jenis konten yang beragam untuk diposting maka proses penjadwalan ini begitu penting agar semuanya bisa terakomodir dengan baik serta tidak merusak tampilan feeds pada profil instagram mal yang dimana salah satu kekuatan dari platform instagram ini ialah pada estetika tampilan yang dapat menarik audience dan pada akhirnya menaikkan engagement konten pada instagram tersebut. Pengelolaan konten dalam tahap penjadwalan ini juga bertujuan untuk akun tetap aktif dimata para followernya karena selalu memberikan update secara periodik. Mengenai jumlah postingan setiap harinya, tidak ada angka pasti yang ditetapkan namun lebih kepada penyesuaian ketersediaan konten ataupun terkait dengan tema-tema tertentu yang sedang menjadi fokus untuk lebih intens di share agar mendapatkan awareness dari khalayak dan tetap diusahakan tidak menjadi konten yang sifatnya mengganggu follower karena kuantitas yang berlebihan. Tidak hanya penjadwalan dari jumlah konten yang akan di-share setiap harinya, namun langkah untuk mengoptimalisasikan konten ini juga memperhatikan waktu posting dengan membaca karakteristik dari khalayak instagram atau biasa disebut dengan prime time instagram. Hal ini bertujuan konten yang diposting akan tepat pada waktu orang-orang sedang banyak mengakses platfrom instagram dan pesan yang disampaikan dalam konten bisa langsung tepat sasaran hingga pada akhirnya menggungah minat khalayak untuk datang ke pusat perbelanjaan (Mall) tersebut. Selain penjadwalan, pengelolaan yang dilakukan untuk lebih optimal dari konten yang di-share ialah penggunaan fitur-fitur penunjang yang ada di instagram untuk lebih menarik dan interakif kepada follower-nya sehingga bisa meningkatkan engagement dari sebuah konten. Pentingnya update perkembangan dan fitur yang tengah trend juga sangat bermanfaat terlebih karakteristik pengguna platform instagram ini ialah generasi muda yang sangat update dengan perkembangan teknologi.

\section{Manage}

Proses pengendalian atau pengaturan dalam sebuah pengelolaan konten media sosial instagram sebuah pusat perbelanjaan (Mall) dilakukan dengan membuat report media monitoring atau laporan perkembangan aktivitas baik untuk konten maupun akun instagram itu sendiri. Hal ini dilakukan untuk mengatur sistem manajemen media korporat dan mengetahui pergerakan yang terjadi pada setiap konten yang diposting seperti respon dan feedback serta data instagram secara keseluruhan. Beberapa indikator yang dilaporkan pada media monitoring kembali lagi pada fokus dan tujuan dari sebuah pusat perbelanjaan (Mall) tersebut menggunakan media sosial instagram. Dari hasil penelitian terlihat bahwa yang menjadi target dari pusat perbelanjaan (Mall) dalam penggunaan media sosial instargam ini ialah pengunjung mal dan instagram digunakan sebagai salah satu strategi dari media komunikasi kepada khalaknya melalui konten-konten yang di-share. Oleh karen itu kualitas konten ialah penting untuk terus termonitor dengan baik seperti jumlah like, comment, ataupun share. Proses monitoring ini berlangsung agar terciptanya sebuah alur yang bermula dari awareness, kemudian engagement, sampai kepada akhirnya yaitu social commerce. Report media monitoring ini juga 


\section{Jurnal Komunikasi Nusantara}

\section{E-ISSN. 2685-7650}

Vol. 2 No. 1 (2020), pp 1-9

DOI: https://doi.org/10.33366/jkn.v2i1.39

sebagai bentuk pertanggung jawaban dari aktivitas pengelolaan konten pada media sosial kepada manajemen perusahaan yang dalam hal ini ialah top manajemen pusat perbelanjaan (Mall). Dari laporan ini yang kemudian menjadi key performance indikator yang dapat dievaluasi dan dijadikan bahan analisa untuk mengambil langkah strategis kedepannya.

\section{Engage}

Tidak hanya dari segi internal dimana dalam pembuatan konten dan diposting pada akun instagram milik pusat perbelanjaan (Mall) sendiri, namun pengelolaan konten juga dilakukan dengan segi ekternal perusahaan seperti halnya bekerjasama dengan komuitas online ataupun public figure agar mendapatkan instagram exposure sehingga konten yang di share akan lebih berdampak pada mal tersebut. Hal ini akan menimbulkan efek bola salju atau yang sering disebut konten viral dalam sebuah instagram. Lain hal-nya proses yang dilakukan ketika bekerjasama dengan komunitas online seperti yang sudah banyak kita temui yaitu para buzzer, selebgram, influencer dan lain sebagainya. Biasanya mereka akan memposting sebuah konten yang mereka hasilkan sendiri yang mereka ambil saat berada di pusat perbelanjaan (Mall)) tersebut untuk kemudian mereka share di instagram pribadi milik mereka dengan penambahan caption yang secara persuasif mengajak follower-nya untuk juga berkunjung ke mal tersebut.

Beberapa aspek secara teoritis dalam hal pengelolaan konten media sosial instagram ini ternyata memang dilakukan secara prakteknnya didalam sebuah perusahaan yang pada penelitian ini ialah pusat perbelanjaan (Mall). Penerapan lebih mendetail mengenai aktivitas pengelolaan pada masing-masing aspek didalamnya juga kembali lagi menyesuaikan dengan tujuan dari penggunaan media sosial tersebut oleh sebuah perusahaan.

\section{Kesimpulan}

Dalam pengelolaan konten pada media sosial instagram korporat, aspek share atau posting menjadi pembahasan pertama yang dimulai dengan memahami tujuan dari penggunaan platfrom media sosial bagi korporat. Selanjutnya pada aspek optimize, pengelolaan konten dilakukan dengan cara membuat jadwal postingan (scheduling) serta pemanfaatan fitur yang tersedia pada platfrom media sosial instagram. Proses pengendalian atau pengaturan (aspek manage) dalam sebuah pengelolaan konten media sosial instagram juga dilakukan dengan membuat report media monitoring atau laporan perkembangan aktivitas baik untuk konten maupun akun instagram itu sendiri. Hal ini dilakukan untuk mengatur sistem manajemen media korporat dan mengetahui pergerakan yang terjadi pada setiap konten yang diposting seperti respon dan feedback serta data instagram secara keseluruhan. Report media monitoring ini juga sebagai bentuk pertanggung jawaban dari aktivitas pengelolaan konten pada media sosial kepada manajemen perusahaan. Dari laporan ini yang kemudian menjadi key performance indikator yang dapat dievaluasi dan dijadikan bahan analisa untuk mengambil langkah strategis kedepannya. Pada aspek engage, pengelolaan tidak hanya membuat konten secara internal namun juga menjalin hubungan baik dengan komunitas online untuk mendapatkan instagram exposure pada konten yang dihasilkan.

\section{Daftar Pustaka}

Ardianto, Elvinaro. (2011). Metedologi Penelitian untuk Public Relations, kuantitatif dan kualitatif. Bandung: Simbioasa Rekatama Media.

Atmoko Dwi, Bambang. (2012). Instagram Handbook Tips Fotografi Ponsel. Jakarta: Media Kita. 


\section{Jurnal Komunikasi Nusantara}

\section{E-ISSN. 2685-7650}

Vol. 2 No. 1 (2020), pp 1-9

DOI: https://doi.org/10.33366/jkn.v2i1.39

Dedy N. Hidayat. (2003). Paradigma dan Metodologi Penelitian Sosial Empirik Klasik. Jakarta: Departemen Ilmu Komunikasi FISIP Universitas Indonesia.

Denzin, Norman K. \& Lincoln, Yvonna S. (2009). Handbook of Qualitative Research. Yogyakarta: Pustaka Pelajar.

Furchan, Arief. (1992). Pengantar Metode Kualitatif. Surabaya: Usaha Nasional.

Kaplan, A. M., \& Haenlein, M. (2010). Users of the World, Unite! The Challenges and Opportunities of Social Media. Business horizons.

Kotler, Philip, Kevin Lane Keller. (2010). Marketing Management, 14th Edition. United States of America: Pearson.

Lexy Moleong. (2004). Metodologi Penelitian Kualitatif. Bandung: Remaja Roesdakarya.

Luttrell, Regina. (2015). Social Media: How to Enggae, Share and Connect. London: Rowman \& Littlefield Publishers.

McQuail, Denis. (2005). Mass Communication Theory Fifth Edition. London: Sage.

Mulyana, Dedy. (2004). Metodologi Penelitian Kualitatif. Bandung: PT Remaja Rosdakarya.

Mulyanto, Agus. (2009). Sistem Informasi Konsep dan Aplikasi. Yogyakarta: Pustaka Pelajar.

Narbuko, Cholid dan Abu Achmadi. (2002). Metodologi Penelitian. Jakarta: Balai Pustaka.

Nelson, R. R., Todd, P. A., and Wixom B. H. (2005). Antecedents of Information and System Quality: An Empirical Examination Within the Context of Data Warehousing. Management Information Systems, 21(4).

Pearson, A., Tadasina, S., Griffin, C. (2012). The Role of Eservice Quality and Information Quality In Creating Website Loyalty. Southern Illinois University, Departement of Management.

Puntoadi, Danis. (2011). Meningkatkan Penjualan Melalui Media Sosial. Jakarta: Gramedia Pustaka Utama.

Satori, Djam'an \& Komariah Aan. (2011). Metode Penelitian Kualitatif. Bandung: Alfabeta.

Scholl, H. (2018). Profit from Facebook Intsagram Stories Marketing Ads. Estalontech.

Simarmata, J. (2010). Rekayasa Web. Yogyakarta: C.V ANDI OFFSET.

Siswoutomo, W. (2009). Panduan Lengkap Membangun Toko Online dengan Joomla untuk Pemula. Jakarta: PT Elex Media Komputindo.

Sugiyono. (2010). Memahami Penelitian Kualitatif. Bandung: Alfabeta.

Sukmadinata, Nana Syaodih. (2011). Metode Penelitian Pendidikan. Bandung: PT Remaja Rosdakarya.

Usman, Husami \& Purnomo Setiady Akbar. (2008). Metodologi Penelitian Sosial. Jakarta: PT. Bumi Aksara.

Zarella, D. (2010). The social media marketing book. Sebastopol, CA: O"Reily Media Inc. 